\title{
A ADEQUAÇÃO DE UM MODELO DE CONSTITUIÇÃO DIRIGENTE ao Direito Penal brasileiro
}

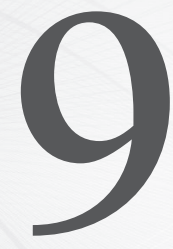

The adequacy of a model of Dirigism Constitucion to the Brazilian Penal Code

Rogerio SganzerLa

Mestrando em Direito pela Unesa. Graduando em Filosofia pela UniRio. Advogado.

Recebido em: 01.03.2012

Aprovado em: 10.04.2012

ÁreA do DIREITo: Constitucional

Resumo: 0 constitucionalismo dirigente merece destaque hoje, principalmente no Brasil, devido ao seu poder de alterar a realidade social através de normas diretivas presentes na Constituição. Porém, por mais que se entenda que esse dirigismo constitucional possa ter sucumbido, é preciso que esse pragmatismo brasileiro se adeque à realidade nacional, cujo sistema criminal ainda depende de diversos ajustes. Para isso serão analisados três assuntos principais: a linguagem como cerceamento de defesa do investigado, a posição do Ministério Público nas salas de audiência e a política pública como fator determinante para a liberação do aborto em uma sociedade. Nessa tentativa, o objeto presente é rever como o sistema criminal ainda se abdica dessa função e como se faz necessária uma revisão da ordem jurídica criminal a fim de adequar-se a essa visão dirigente que o Brasil tanto precisa buscar.
ABSTRACT: Dirigisme Constitutionalism deserves highlight today, mainly in Brazil, due to its power to alter reality through social policy standards present in the Constitution. But however it is understood that this constitutional dirigisme may have succumbed, it is necessary that this pragmatism suits to the Brazilian reality, whose criminal system still depends on several settings. For this, will be considered three main issues: language as stifling defense of the accused, the position of the prosecutors in the courtrooms and the need for public policy of abortion. In this attempt, the present object is to review how the criminal justice system still abdicates that role and how is it necessary to revise the criminal law in order to conform to this vision leader that Brazil must both seek. 
Palavras-chave: Direito Penal - Jurisdição constitucional - Constituição dirigente - Linguagem - Aborto.
KeYwords: Criminal Law - Constitutional jurisdiction - Dirigisme Constitucionalism language - Abortion.

SumÁRIO: 1. Introdução - 2. Jurisdição constitucional e Constituição dirigente - 3. 0 sistema criminal à luz de uma Constituição dirigente - 4. Conclusão - 5. Bibliografia.

\section{INTRODUÇÃO}

Os direitos sociais são alvo das mais controversas discussões sobre a efetividade dos dispositivos presentes na Constituição. Há uma enorme discussão se os artigos que delimitam as ações do Estado servem de caráter vinculativo, delimitador ou simplesmente balizador das ações do Governo. Por isso, a tentativa será de buscar uma resposta do quanto a Constituição brasileira de 1988 está engajada nesse particular.

Para tanto, será usada a tese de Canotilho de Constituição dirigente, revisitada pelo modelo de Lenio Streck a países de modernidade tardia. Essa fórmula ajudará a entender que tipo de efetividade se pode esperar de normas programáticas presentes na Constituição de 1988. Estas normas em estudo, não somente limitadas a direitos sociais, mas também aos princípios e diretos e garantias fundamentais, ajudarão a averiguar se o sistema criminal como um todo está voltado a essa realidade constitucional ou se a realidade social está em descompasso com o compromisso dirigente.

\section{JURISDIÇÃO CONSTITUCIONAL E CONSTITUIÇÃO DIRIGENTE}

A jurisdição constitucional surge como uma forma de dar legitimidade e função à Constituição. A legitimidade sustenta a Constituição em dois pontos principais: o conteúdo mesmo de seu texto e o fato de emanar a vontade do povo, seja pela Assembleia Constituinte, seja pelo referendum. Já a função da Constituição objetiva a garantia de direitos dos cidadãos, impedindo que os Estado os viole, fazendo com que o texto constitucional seja rígido e inflexível. Logo, conforme aduz Ferrajoli, não há simplesmente uma extensão do respeito à legalidade à todos os poderes, mas também um programa político futuro, porque impõem a todos os poderes imperativos negativos e positivos como fonte de sua legitimação, porém também, e sobretudo, de deslegitimação.

Dessa forma, as Constituições passam a conter ações e suas normas possuem eficácia, tendo o Direito deixando de ser um mero instrumento para a aferição da parametricidade formal. A soberania do parlamento e a intangibi- 
lidade e onipotência do legislador parlamentário perdeu terreno em favor da concepção de soberania da Constituição e do caráter constituído e subordinado do Poder Legislativo. Para tanto, torna-se imprescindível a intervenção de um poder mediante o instrumento de controle de constitucionalidade para o reconhecimento e exercício desse papel da justiça constitucional.

A jurisdição constitucional, principalmente através do Poder Judiciário, passa a ser o cerne da questão sobre como se dará o tipo de atuação almejado pela Constituição. O principal questionamento evolve o excesso de ativismo judicial. Para Lenio Streck não se pode falar que houve no Brasil essa postura ativa se comparada àquelas presentes em Tribunais Europeus, em especial à Alemanha. Essa postura self restraint, exemplificada pelo esvaziamento do mandado de injunção, tem origem em alguns fatores: (a) os curtos períodos de democracia vividos pelo País e a consequente falta de autonomia do STF, as primeiras décadas de controle difuso sem mecanismos de extensão dos efeitos das decisões, a tardia inserção do controle concentrado de constitucionalidade (apenas em 1965), o tardio ingresso do Brasil na era do constitucionalismo do Estado Democrático de Direito, entre outros.

Independente do entendimento a favor ou contra a presença ou não do ativismo no Brasil, certo é que há necessidade de preservar, dentro do Estado Democrático de Direito, seus dois pilares: democracia e direitos fundamentais. Não há democracia sem o respeito e a realização dos direitos fundamentais-sociais, e não há direitos fundamentais-sociais sem democracia. Nessa proteção, de forma expansiva, o judiciário é acusado de proferir sentenças consideradas "invasoras de subsistemas" ou "judicializadoras da política". Entretanto, o principal é que "a Constituição, além de ser o elo conteudístico que une "política e direito" em um determinado Estado, é também um eficiente remédio contra maiorias. E ao se constituir um remédio contra maiorias (eventuais ou não), tem-se que a Constituição, enquanto explicitação do contrato social, traz ínsito um núcleo político que somente pode ser extirpado/solapado a partir de uma ruptura institucional" (STRECK, 2004, p. 111).

Por isso, ao defender a democracia e os direitos fundamentais, o Poder Judiciário legitima-se como órgão estatal cuja função é a de resguardo dos fundamentos do Estado de Direito. Enquanto fundamentos tornam-se essenciais e assim, existenciais. O Estado Democrático de Direito condiciona nosso agir-no-mundo, porque faz parte de nosso modo-de-ser-no-mundo. Não é algo separado de nós, sendo alcançado pré-ontologicamente.

Por essa razão, Canotilho afirma que não se deveriam entender essas normas como puramente programáticas (declarações, sentenças políticas etc.), mas sim como pertencentes de valor jurídico constitucionalmente idêntico ao 
dos restantes preceitos da Constituição. Em outros termos, essas normas deveriam ser entendidas como vinculadoras do legislador de forma permanente à sua realização, pois vinculam todos os órgãos concretizadores, e também como limites negativos, justificando eventual censura, sob forma de constitucionalidade, em relação aos atos que as contrariam.

Entretanto, numa crítica a esse sistema, o próprio doutrinador diz que as Constituições dirigentes padecem de um pecado original chamado de "má utopia do sujeito projetante", pois se transformou o Direito em instrumento funcional dessa direção a ser perseguida. Além disso, o constitucionalismo programático não se deu conta da complexidade do mundo e das consequências das integrações entre as nações. Conclui, então, que:

"a Constituição dirigente está morta se o dirigismo constitucional for entendido como normativismo constitucional revolucionário capaz de, só por si, operar transformações emancipatórias" (СаNotilho, 1989, p. 132).

Em termos gerais, Lenio Streck resume e expõe suas críticas. A crítica de Canotilho à filosofia do sujeito não é, como erroneamente se poderia supor, a crítica à metafísica do sujeito (objeto, por exemplo, de crítica pela ontologia fundamental de cariz hermenêutico), mas sim, a uma "racionalidade cognotivo-instrumental", pela qual o sujeito "cognoscente" intervém na "ordem do mundo" (Habermas). Assim, quando Canotilho faz uma crítica à filosofia do sujeito, está se referindo a uma crítica à teoria da subjetividade, que pretende, ao que tudo indica, substituir pela categoria da intersubjetividade ou do diálogo consensual (racionalidade comunicativa), na tradição frankfurtiana da teoria crítica. Como o homem está inserido em um mundo constituído a partir da linguagem, que lhe antecede, a Constituição não teria sentido sem a compreensão prévia do sentido. Assim, não teria sentido falarmos nessa compreensão prévia sem que estivéssemos lidando com o sentido mesmo da Constituição, no nível do cotidiano e da interação social. A linguagem constituinte, da busca do novo, passa a ser condição de possibilidade desse novo, pela exata razão de que, na tradição engendrada pela noção de Estado Democrático de Direito, o constitucionalismo já não é mais o de índole liberal, mas sim um constitucionalismo produto de um constructo que estabelece, em um novo-modo-de-ser instituído pelo pacto constituinte, os limites do mundo jurídico social. O direito assume uma nova feição: não mais a proteção do indivíduo, enquanto mônada, pretensamente autônomo, mas sim a proteção e implementação dos direitos fundamentais-sociais até então sonegados pelo paradigma liberal-individualista-normativista, o qual se calca na filosofia do sujeito e na filosofia da consciência. 
Nesses termos, expõe ainda Lenio Streck, caso a afirmação de Canotilho de que "a Constituição dirigente está morta se o dirigismo constitucional for entendido como normativismo constitucional revolucionário capaz de, só por si, operar transformações emancipatórias", tal afirmação não elimina e tampouco enfraquece a noção de Constituição dirigente. A Constituição (e cada uma) depende de sua identidade nacional, das especificidades de cada Estado Nacional e de sua inserção no cenário internacional. Do mesmo modo, não há "um constitucionalismo", e sim vários constitucionalismos. Enquanto que a Constituição de Portugal apontava claramente para a transformação do modo de produção do Estado português, a Constituição do Brasil limitou-se a apontar para a transformação do modelo de Estado (Estado Democrático de Direito), restringindo-se, no plano econômico, a estabelecer as bases (núcleo político) de um Estado Social (Welfare State).

Ou seja, além do núcleo mínimo universal que conforma uma teoria geral da Constituição há um núcleo específico de cada Constituição que se diferenciará de Estado para Estado. Propõe-se, então, uma Teoria da Constituição Dirigente Adequada a Países de Modernidade Tardia (TCDAPMT), cujo núcleo de direitos sociais-fundamentais plasmados em cada texto atenda ao cumprimento de um conteúdo compromissório mínimo, bem como os correspondentes mecanismos de acesso à jurisdição constitucional e de participação democrática, constituindo, assim, condições de possibilidade para o resgate das promessas da modernidade incumpridas.

Quando se fala em Constituição dirigente não se está (nem se poderia estar) sustentando um normativismo constitucional capaz, de, por si só, operar transformações emancipatórias. O que permanece da noção de Constituição dirigente é a vinculação do legislador aos ditames da materialidade da Constituição. Ao propugnar o "dirigismo constitucional" a pretensão é a de que se utilizem eficazmente os mecanismos constitucionais postos à disposição do cidadão e das instituições. A Constituição não é uma simples ferramenta, mas sim algo que constitui. A força normativa da Constituição não pode significar a opção pelo cumprimento ad hoc de dispositivos "menos significativos" da Lei Maior e o descumprimento sistemático daquilo que é mais importante - o seu núcleo essencial-fundamental.

Conclui Lenio Streck: uma Teoria da Constituição Dirigente Adequada a Países de Modernidade Tardia (TCDMAPMT) significa mais do que assegurar os procedimentos da democracia - que são absolutamente relevantes; é preciso entender a Constituição como algo substantivo, porque contém valores (direitos sociais, fundamentais, coletivos lato sensu) que o pacto constituinte estabeleceu como possíveis de realização. Por tudo isso, há que deixar assen- 
tado que o constitucionalismo dirigente compromissório não está esgotado. A Constituição ainda deve "constituir-a-ação". No texto da Constituição de 1988 há um núcleo essencial não cumprido, contendo um conjunto de promessas da modernidade, que deve ser resgatado. O problema é que, em países como o Brasil, formou-se um "silêncio eloquente" acerca do significado da Constituição, naquilo que ela tem de "norma diretiva fundamental". Numa palavra sob o mato de uma "baixa constitucionalidade", olvidou-se o constituir da Constituição; mas, muito pior do que o silêncio é não prestarmos atenção nele.

\section{O Sistema CRIMINAl À lUZ dE UMA CONSTituiçÃO DIRIGENTE}

Normalmente, ao comparar a normatização infraconstitucional anterior ao sistema constitucional vigente fala-se que deverá haver uma filtragem constitucional a fim de equalizar todo o sistema positivo anterior com as diretrizes da nova Constituição. Ao fazer isso, o que não é novidade, tem-se uma derrogação da legislação anterior com ela incompatível e uma atuação conforme esses novos rumos.

Usualmente, na perspectiva penal constitucional, é empregado um entendimento exclusivamente programático e simplista, no qual há uma visão passiva e futurista sobre as regras criminais. Num olhar penal constitucional dirigente esta perspectiva se torna vinculativa e presente, pois a essência constitucional que merece ser preservada é atual e imanente do Estado Democrático de Direito.

Como a Constituição Brasileira de 1988 é uma Constituição dirigente, há necessidade de incorporar esses programas no sistema criminal vigente. $\mathrm{O}$ ponto é que não é somente uma necessidade de atuação passiva e derrogação de toda a incompatibilidade anterior, mas sim uma postura ativa e incorporação das diretrizes impostas no rol de direitos sociais e fundamentais no ordenamento infraconstitucional.

O exame se espreita pelos diversos ramos do Sistema Criminal, incluindo assim leis extravagantes, interpretações e o Código Penal e Processual. A seguir, será feita uma análise de considerações que ainda devem ser perseguidas pelo sistema à luz de uma Constituição dirigente, decompondo as regras programáticas de forma a visualizar se o dirigismo constitucional pode ser tido como presente, ausente ou ineficaz defronte a Constituição brasileira de 1988.

Primeiramente, uma diretriz importante trazida pela Constituição em torno do Direito Penal foi a transposição de um sistema inquisitivo para um sistema acusatório. A Constituição de 1988 depurou/purificou o sistema acusatório de processo penal que o Código de 1942 adotava. O processo penal brasileiro 
sempre foi predominantemente acusatório, tendo resquícios de um processo penal inquisitivo.

A Constituição deu ao Ministério Público a exclusividade de promover a ação penal de natureza acusatória. Esta se diferencia do processo penal inquisitivo ao passo que naquele há absoluta separação na função de acusar e julgar. Quem julga não acusa e quem acusa não julga. No processo inquisitivo, quem julga e acusa são os mesmos sujeitos processuais. Além disso, no processo acusatório, que é um processo de partes, as funções de julgar, acusar e defender são atribuídas a sujeitos processuais diversos.

Porém, o inquérito policial se manteve ausente dessa "purificação". Justifica-se ainda a persistência de tal inquisitividade pelo fato de tratar-se de um procedimento no qual não há acusação devidamente formalizada e inexiste imputação formal. Como não há imputação formal, inexiste ampla defesa e contraditório. A autoridade policial conduz discricionariamente as investigações, ordenando a realização das diligências que considerar necessárias ou úteis ao esclarecimento do fato criminoso, de suas circunstâncias e autoria, a fim de que se torne possível, ao Ministério Público, o oferecimento da denúncia.

Mais ainda. Na condução do inquérito policial, o delegado não se sujeita a um rito (sequência preordenada de diligências investigatórias previstas em lei). Diferente do processo penal, este tem um rito predeterminado.

Atualmente, como característica mais marcante, não é correto afirmar que o indiciado é um mero objeto da investigação. Hoje, não obstante a característica inquisitiva, o indiciado é visto como sujeito de direito porquanto a persecução penal não pode violar direitos e garantias fundamentais do indivíduo. Porém, isso não garante a ampla defesa ou contraditório, pois nesta fase ainda não há acusação formal.

Independente disso, não pode a inquisitividade de um procedimento ser protegida pela argumentação de que uma "simples" acusação é a peça chave para vários atos que possam transgredir os direitos previstos na Constituição. $\mathrm{O}$ dirigismo constitucional, além de determinar que os direitos fundamentais serão as peças fundamentais desse novo sistema pós-inquisitivo, possibilitou também a capilarização das regras democráticas em todos os sistemas. Por isso, tal justificativa não deve prosperar.

O ponto fundamental é que a inquisitividade do procedimento policial, por mais que não vislumbre qualquer acusação, é elemento essencial para a elaboração dessa acusação, o que torna essa conduta incompatível com aquilo que é determinado pela Constituição.

A defesa que aqui se faz é que o sistema acusatório também faça parte do inquérito policial em virtude da linguagem utilizada. A fundamentação para 
este entendimento suporta todos os atos formais instrutórios do procedimento policial que possam gerar alguma imputação formal sobre o acusado, Assim, seja no interrogatório, seja na reconstituição do crime, deve ser obrigatória a presença de um advogado para que seja considerado tal ato válido.

Semelhante à ação penal, o inquérito policial demanda das mesmas necessidades, mas com fundamentos distintos. No processo penal a presença do advogado é obrigatória tendo em vista o direito de defesa e assistência processual, ainda que gratuita. Já no procedimento policial a justificativa do direito de defesa é frágil, haja vista que não há acusação formal e o direito do acusado poderia ser ponderado com a viabilidade da investigação. Dessa forma, para fugir dessa teia viciada de argumentação que levaria a uma inquisitoriedade do procedimento, é preciso ver aquilo que caracteriza a essência do inquérito policial.

Então, a linguagem assume esse papel. Pelo fato do sistema instrutório pré-processual ser de natureza investigativa, são congênitas diversas ações inquisitivas e unilaterais de forma a resolver os crimes que se proliferam na sociedade. Tendo o Ministério Público ao seu lado, é natural e bastante claro que há uma obrigação de apurar os fatos da melhor forma possível e achar os agentes que atuaram naquela conduta.

O Ministério Público exerce o controle externo da atividade policial. Esse controle é o da investigação criminal no qual o Ministério Público é o destinatário direto. Deve ser visto sobre duplo aspecto: legalidade e efetividade da investigação policial. A legalidade, pois a Constituição proíbe provas ilícitas (não prova), não podendo instaurar inquérito policial com base nelas. Além disso, é efetivo no sentido que o inquérito policial deve apurar o fato criminoso de modo a reunir provas para tal.

O controle não vislumbra qualquer hierarquia entre Ministério Público e Polícia. Há uma subordinação processual porque a polícia tem que cumprir as requisições do Ministério Público. Não há no rol das funções do Ministério Público remissão expressa à instrução criminal como função institucional, e também não há proibição da Constituição para o Ministério Público no exercício de atos de investigação criminal. Além disso, segundo o STJ, de acordo com a sua Súmula $234,{ }^{1}$ há possibilidade de investigação pelo Ministério Público, o que, segundo o STF, também era válido e viável, seguindo a mesma linha de entendimento. Porém, uma decisão do órgão negou a possibilidade de inves-

1. "A participação de membro do Ministério Público na fase investigatória criminal não acarreta o seu impedimento ou suspeição para o oferecimento da denúncia." 
tigação pelo Ministério Público. A argumentação foi de que esta função era estritamente da autoridade policial. Não obstante, mais ainda, entre sucessivas mudanças de entendimento, a Min. Ellen Gracie, no RE 535.478, afirmou que a atuação do Ministério Público aperfeiçoaria a persecução penal, o que daria a legitimidade concorrente (e em algumas hipóteses) de atuação do Ministério Público junto à autoridade policial. Ainda assim, não há qualquer manifestação definitiva do Pleno sobre esta questão, havendo diversas ações diretas no STF aguardando o julgamento de mérito (ADIns 2.943, 3.309, 3.317, 3.318, 3.329, 3.337, 3.340, 3.349, 3.806, assim como o Inq 1.968).

Então, partindo do princípio que o Ministério Público pode participar da investigação criminal, o investigado pelo procedimento policial (cuja participação pode conter, exclusivamente, a autoridade policial, como também, o Ministério Público) terá sobre si uma inquirição sobre determinado fato delituoso. Por mais que o procedimento inquisitivo não tenha uma acusação formal, é tendencioso que essa investigação do fato seja feita pela mesma pessoa que irá lhe apresentar uma denúncia. Esta conduta do Ministério Público, ainda que possível, é duvidosa.

O ponto, assim, fica claro. Por mais que a defesa do acusado não seja o ponto principal para quebrar o argumento da inquisitoriedade do procedimento, é evidente que aquela pessoa formalmente investigada, por mais que não queira uma defesa (ou não a requeira), terá que tê-la, pela simples justificativa de que a linguagem utilizada na investigação do ato poderá ocasionar a imputação de determinado fato a alguém.

Essa imputação é um marco importante para o Direito, pois, com isso, poderão ser utilizados diversos mecanismos de restrição de direitos. Logo, se determinada ação investigativa pode acarretar essa restrição, é certo que o acusado merece uma defesa. A linguagem utilizada, assim, merece destaque. Como filtro dessa mensagem está o advogado. Sua função é captar a mensagem da melhor forma que o seu significado seja recebido.

Explica-se: a relação emissor/receptor é baseada no texto e na realidade. Conforme José Carvalho explicita, para o emissor, o que se apresenta primeiro são os significados parciais e o significado total que representa a nova síntese e, com estes e ligados a estes, os significantes (parciais e total) que, no próprio ato em que os "procura", ele produz materialmente, construindo com eles o texto transmitido. Em outras palavras, primeiro há a análise mental daquilo que é realidade; posteriormente, traduzido em texto, há os significantes (1973, p. 347-377).

Para o receptor, é o significante (total) ou os significantes (parciais) que primeiro se apresentam, impressionando os seus sentidos externos, levando-o 
logo, por seu intermédio, ao conhecimento do significado, e por fim, da realidade conhecida pelo emissor. Representando assim o processo tem-se a partir do emissor um movimento que sai da realidade e segue através do significado até o significante, e logo, em sentido inverso, deste, através do significado, se dirige até a realidade:

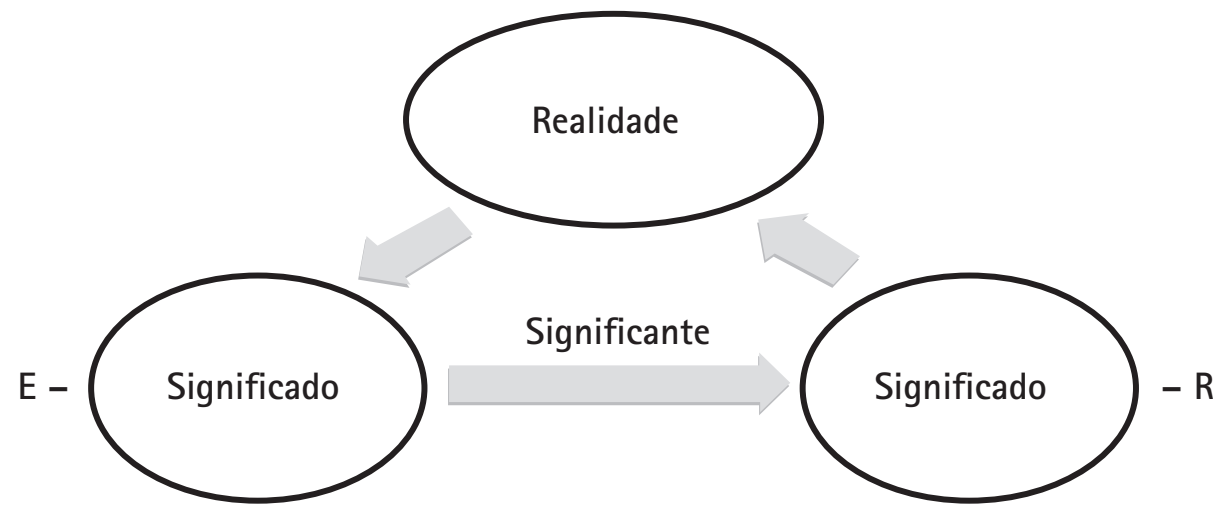

Essa relação seria completamente sistemática se não houvesse um elemento crucial nessa relação: a compreensão. Para atingir essa finalidade, o receptor tem de agir, realizando o ato a que chamamos de interpretação ou processo interpretativo, que essencialmente consiste em, uma vez recebido o texto, determinar aí as relações significativas que nele quis manifestar o sujeito que o produziu, de maneira a fazer em sentido inverso, entre o significante e a realidade, o caminho percorrido pelo emissor.

Em resumo, pois aqui não se trata em específico deste tema, como a investigação policial é atividade persecutória e a compreensão da linguagem feita pelo receptor (investigado) pode ser feita de maneira diversa da pretendida pelo emissor (autoridade), a função do advogado como filtro dessa relação se torna essencial e imprescindível para que a realidade da mensagem seja atendida e não haja uma autoincriminação por parte do investigado. Como não se trata de uma interpretação normativa que possibilita diversos sentidos, a mensagem produzida formalmente por uma autoridade deve ser única e não produzir duplicidades interpretativas. Não somente isso, o "erro" pode estar tanto no emissor quanto no receptor. No processo penal presume-se que o indivíduo esteja em posição debilitada e necessite a presença do advogado. No inquérito policial também deve ter a mesma presunção, o que justifica a necessidade do defensor.

Portanto, na diretriz constitucional dirigente e na tentativa de firmar a concretização de direitos fundamentais e principiológicos na esfera penal, faz-se 
extremamente necessária a obrigatoriedade da presença de defensor em atos formais realizados durante a investigação preliminar presidida pela autoridade policial com ou sem a presença do Ministério Público para a configuração da sua validade processual, tendo em vista o possível vício de linguagem presente tanto na emissão quanto na recepção, sendo assim presumida a incapacidade de compreensão da realidade textual pelo investigado.

Além disso, outro assunto que merece um olhar atento é a posição do Ministério Público em salas de audiências ao lado do Juiz. Esta questão deve ser enfrentada em pouco tempo pelo Poder Judiciário. Recentemente, um voto no Pleno do Conselho Federal da OAB, sob o relato de Rodrigo Badaró de Almeida Castro, concordou na propositura de uma Ação Direta de Inconstitucionalidade em virtude do art. 18, I, a, da LC 75/1993, cujo objeto dispõe sobre a organização, as atribuições e o Estatuto do Ministério Público da União.

A argumentação baseia-se na paridade de armas, no devido processo legal e no sistema acusatório. Da mesma forma que a emancipação inquisitiva se deu no processo penal para um sistema acusatório, um passo extremamente importante foi a institucionalização e estruturação do Ministério Público tal como é hoje. Nessa linha, com a sua dupla função fiscalizatória e acusatória, é um órgão de defesa da ordem jurídica, do regime democrático e dos interesses sociais e individuais indisponíveis, conforme o art. 127 da CF/1988.

Assim, pela natureza de órgão de Estado, não de governo, deve atuar pelo novo sistema imposto constitucionalmente, qual seja, atuando como parte, ao ponto da legitimidade ser conferida diretamente aos indivíduos que o integram e não à instituição; até uma organização mais vinculativa aos poderes do Estado, conforme se verifica na França, Alemanha, Espanha e Holanda, países em que o Ministério Público é ligado ao Poder Executivo, muito embora seja dotado de garantias e prerrogativas semelhantes à dos magistrados, situação distante da realidade brasileira.

Na história mundial, dois são os modelos que valem de comparação com o brasileiro. De um lado está o modelo francês no qual o Ministério Público é vinculado ao Estado, tendo status de magistrado, mas estando sujeito à direção e controle de seus superiores nos quadros de carreira e por estarem submetidos à supervisão do Ministério da Justiça. Do outro lado, nos Estados Unidos, por mais que seja um órgão não eleito, a principal característica é a atuação eminentemente criminal cujos poderes são a paridade de armas, liberdade de atuação, retratação em casos de erros, entre outros.

O que se conclui inevitavelmente é que qualquer que seja a visão adotada, o Ministério Público é um órgão independente e ao mesmo tempo diferente da Magistratura. Como já dito, a Constituição veios expurgar determinados males 
presentes na ditadura brasileira e um deles foi essa união de funções. O membro do Ministério Público deve opinar quando fiscal da lei e como parte deve buscar o convencimento do julgador como os advogados, sem qualquer diferença.

As atribuições do Ministério Público direcionadas e dirigidas pela Constituição Federal de 1988 ainda não foram atendidas em tal ponto e merecem uma revisão infraconstitucional. Tal como dito, o sistema penal se permeia de vícios da idade média cujos resquícios ainda fazem do processo penal uma batalha épica medieval.

Por ter essa dupla atuação (fiscalizatória e acusatória), quando o órgão atua como parte, deve se submeter aos mesmos preceitos que os do advogado. Não pode prosperar a argumentação de que se trata de uma instituição independente e essencial à justiça, pois da mesma forma que o órgão, o advogado é função imanente do Estado, não podendo um viver sem o outro, caso contrário, viver-se-ia ou num Estado inquisitorial ou num Estado sem leis.

Então, a ocupação de um lugar diferente na sala de audiência simplesmente pelo fato de ser um órgão diferente é algo a se discordar. Quando atua na sua função fiscalizatória, razoável que sim. Porém, como parte, parece ser uma quebra de atribuição e um ferimento à isonomia, paridade de armas e devido processo legal.

Portanto, a atuação do legislador positivo deve ser no respeito dessas normas. Como intervém Carlos Roberto Siqueira Castro, quando ele atua em descompasso com elas, vide a elaboração do art. 18, I, a, da LC 75/1993, se está criando uma discriminação legislativa com direitos considerados fundamentais e, por isso mesmo, assegurados de modo explícito ou implícito na Constituição (1983, p. 75). Há claramente um abuso de direito ao tentar se colocar como diferente mesmo em posição de direito e de fato igualitárias, sem qualquer critério objetivo ou finalista que possa respaldar que a ocupação daquele espaço contribua para o cumprimento de suas atribuições, ainda mais como parte, em detrimento dos mesmos direitos, responsabilidades e prerrogativas dos advogados.

A consequência disso é um sério dano à defesa e à democracia. Num lugar onde há uma equidistância física entre juiz e acusador, não pode o Estado falar que o sistema inquisitivo foi purificado. A relação deveria ser isonômica e ao indivíduo comum resta a visão de indecisão sobre quem é quem durante a audiência, não sendo raro também a confusão de funções entre acusador e magistrado durante o manuseamento da palavra, conversas "de pé de ouvido", tons exaltados, entre outros. O que se presume é a subordinação da defesa com o processo perante o Ministério Público. O acusado passa a tratar aquele que o acusa como um ente superior e a importância de sua defesa fica em segundo plano. 
Novamente vale o argumento de que não somente o direito à defesa é o centro das atenções, mas também a linguagem utilizada, não só resumida em escrita, mas também corporal. Quando exposta a público, esta sensação de equidistância entre julgador e acusação suporta um ônus ao acusado, que necessita do advogado para lhe defender desse peso. Como esse dano ou carência de defesa é presumido, a função do advogado é equilibrar e sopesar a balança, dando suporte a ele no processo. Porém, no caso, o que se vê não é mais uma presunção, mas sim o real dano à parte, pois a linguagem imposta sobre ele é de obediência e submissão perante aquele que o acusa. Nesse ponto, nem mesmo o advogado pode lhe ajudar, tendo em vista que este também está em mesmo plano que ele. Assim, qualquer que seja a atuação do advogado a identidade física do Ministério Público no processo já exterioriza uma posição superior ao advogado através de sua linguagem institucional e estrutural dentro da sala de audiência.

Por tudo isso, resta ainda tal vértice para que seja alcançado o equilíbrio do sistema penal nos moldes de um sistema páreo e equidistante, no qual as diversas mazelas inquisitivas sejam enxugadas da ordem jurídica de modo a atender as diretrizes constitucionais dirigentes que a sociedade tanto demandou e ainda não foram cumpridas.

Por fim, resta tratar de um tema particularmente sensível e que necessita de melhores discussões para o esclarecimento da questão: a permissão do aborto. Por se tratar de bens juridicamente previstos na Constituição, ao se falar em aborto e restringir a discussão a um debate simplista de ponderação de direitos, esquece-se que a questão é mais ampla que tal ponto.

Como dito por Canotilho, o constitucionalismo dirigente está morto se as suas normas estiverem sendo entendidas como emancipatórias por si só. O que se precisa é uma atuação político-legislativa a fim de satisfazer os preceitos jurídicos positivados na Constituição. Assim, ao se falar especificamente do tema do aborto, não é possível atender ao dirigismo constitucional da liberdade e intervencionismo estatal sem levar em conta a necessidade de uma política pública nesse setor. Conforme é exposto em artigo de forma mais abrangente, defende-se a necessidade de uma política pública específica como condição $a$ priori para que seja permitido o aborto. Através da liberdade individual, e por mais que haja a ponderação com a vida, assume-se que o aborto só passará de uma visão simplista de disponibilidade de uma vida para uma visão de planejamento familiar.

A questão fundamental, então, está em tomar um foco predecessor e entender se o Estado tem possibilidade fática de preferir determinados direitos ao invés de outros, tendo em vista o seu grau de comprometimento social. Simplificando: o Estado seria capaz, caso quisesse, de permitir o aborto e não fazer disso um problema? 
Dessa forma, um primeiro questionamento que se deve ter é se o Estado, ao decidir discriminalizar o aborto, possui obrigações com esta atitude ou simplesmente pode deixar o mercado e a sociedade se relacionarem arbitrariamente.

O principal foco ao se falar em aborto deve ser, então, visualizar se há ou não uma política pública eficiente para que não aconteça o resultado inverso ao esperado, qual seja, agravamento da saúde pública, aumento da pobreza, problemas de desenvolvimento, doenças e mortes prematuras, aumento do abandono escolar, delinquência juvenil, instabilidade familiar e divórcio, entre outros.

A razão de se falar em uma política pública eficiente está no fato de que, ao permitir o aborto, nascem consequências que podem ou não serem vistas como obrigações, dependendo do modo como o Estado lida com sua visão de bem-estar. Contudo, indiscutivelmente, essa visão não influencia a consequência na qual se chegará: o retrato oposto do que se quer alcançar.

Independente de o Estado prezar pelo bem-estar social (Welfare State) de forma intensa ou se abster do controle econômico, político e social, a política pública, seja pensada a priori ou a posteriori da descriminalização do aborto é necessária. O fato de o país ser mais ou menos intervencionista não altera a sua negligência com o setor, mas tendo este mesmo Estado adotado uma postura intervencionista, é possível que as possibilidades de uma política pública deste porte estar presente aumentem, haja vista que menores são as taxas de aborto realizados em países cujo histórico foi de um bem-estar social.

O desenvolvimento do país, obviamente, influencia a adoção desta política púbica na medida em que sua economia pode bancar ou não estes pressupostos. Caso contrário, arcará ainda mais com o ônus social e econômico da negligência, gerando mais problemas na população ou agravando os anteriormente existentes.

Resta, assim, ao Brasil questionar se há condições para exigir a descriminalização do aborto ou se trata de uma questão acima de questões fáticas e casuístas. Num país com analfabetismo alto, alto índice de mortalidade infantil, desemprego, ${ }^{2}$ entre outros, pode haver a descriminalização do aborto? Mais ainda, tendo em mente essas deficiências, não seria (mais) questionável então a sua proibição, haja vista que o Estado não garante alguns direitos e exige outros deveres? Qual o limite do Estado em exigir algo que não (talvez) lhe seria obrigado a fazer?

A resposta é sempre questionável. A única coisa que não pode ser feita é ficar parado na esteira do tempo e não adotar uma postura, seja ela proativa

2. Considerações feitas a partir do site da Central Intelligence Agency (CIA) sobre a comparação de diversas taxas em países do mundo. Disponível em: [https://www.cia. gov/library/publications/the-world-factbook]. Acesso em: 28.11.2011. 
ou reativa. A responsabilidade recairá de qualquer forma. O que se precisa é adotar um lado, e para que seja possível a descriminalização do aborto, uma posição acertada numa política pública de elementos concretos e estudos aprofundados sobre as consequências em determinada sociedade.

\section{Conclusão}

A partir das considerações feitas, tentou-se trazer o entendimento do constitucionalismo dirigente como ainda presente e necessário para a concretização dos preceitos existentes na Constituição brasileira de 1988. Para isso, foram levantados os ensinamentos de Canotilho e Lenio Streck, cujas posições convergem para uma aplicação vinculante das diretrizes constitucionais, as quais estariam sem eficácia se não fossem aplicadas desta maneira. A alternativa construída e trazida ao trabalho foi a de uma Teoria da Constituição Dirigente Adequada a Países de Modernidade Tardia, cuja aplicação ao específico caso brasileiro é de trazer aplicabilidade (e não apenas um simples programa) ao dirigismo trazido pelo legislador constituinte.

Dessa forma, três assuntos principais foram tratados como sendo essenciais para se chegar a uma adequação dessa teoria constitucional. A primeira é a linguagem como cerceamento de defesa do investigado com a obrigatoriedade da presença do advogado em atos formais do inquérito policial, a segunda é a inconstitucionalidade da posição do Ministério Público em salas de audiências e a terceira é a necessidade de uma política pública adequada para a permissão do aborto.

Assim, é imprescindível que se continue nessa constante promoção de valores no ordenamento infraconstitucional de forma a dar efetividade às normas programáticas presentes na Constituição. Tais exemplos citados no trabalho representam alguns dos assuntos que ainda precisam de adequação. Ainda assim, restam outros temas que precisam ser reformulados tendo em vista a vinculação que o legislador possui com o dirigismo constitucional. Não é possível haver um esquecimento desses programas, pois, do contrário, chegar-se-á à conclusão de Canotilho sobre o fracasso do dirigismo constitucional em países europeus: largamos atrasados, ficamos atrás e ainda abandonamos a corrida sem completá-la.

\section{Bibliografia}

Canotilho, José Joaquim Gomes. Direito constitucional. 4. ed. Coimbra: Almedina, 1989.

Carvalho, José G. Herculano de. Teoria da linguagem - Natureza do fenômeno linguístico e a análise das línguas. 3. tir. Coimbra: Atlântida, 1973. 
Castro, Carlos Roberto Siqueira. O princípio da isonomia e a igualdade da mulher no direito constitucional. Rio de Janeiro: Forense, 1983.

Cherry, Colin. A comunicação humana. Trad. José Paulo Paes. São Paulo: Cultrix, 1971.

EsPing-Andersen, Gosta. O futuro do Welfare State na nova ordem mundial. Lua Nova. n. 35. p. 73-111. São Paulo, 1995.

Human Development Report 2009 - Table G: Human development index trends. Programa das Nações Unidas para o Desenvolvimento. Disponível em: [http://hdr. undp.org/en/media/HDR_2009_EN_Indicators.pdf]. Acesso em: 27.11.2011.

Kenworthy, Lane. Do social-welfare policies reduce poverty? A cross-national assessment. Luxembourg Income Study Working Paper. n. 188. Social Forces. vol. 77. issue 3. p. 1119-1139. Oxford University Press, 1999.

LevitT, Stevem D. Understanding why crime fell in the 1990s: four factors that explain the decline and six that do not. Journal of Economic Perspectives. vol. 18. n. 1. p. 163-190. Winter 2004. Disponível em: [http://pricetheory. uchicago.edu/levitt/Papers/LevittUnderstandingWhyCrime2004.pdf]. Acesso em: 26.11.2011.

Netherlands Ministry of Foreign Affairs. Questions and answers on Dutch policy on abortion, 2003. Disponível em: [www.minbuza.nl/binaries/content/ assets/ minbuza/en/import/en/you_and_the_netherlands/about_the_netherlands/ ethical_issues/faq-abortus-2010-en.pdf]. Acesso em: 28.11.2011.

ОкоnоғUA, F. Abortion and maternal mortality in the developing world. Journal of Obstet Gynaecol Canada. 28(11). p. 974-979. Vancouver, nov. 2006.

STRECK, Lenio Luiz. Jurisdição constitucional e hermenêutica. 2. ed. Rio de Janeiro: Forense, 2004.

Verdade e consenso. 2. ed. Rio de Janeiro: Lumen Juris, 2008.

Tourinho Filho, Fernando da Costa. Processo penal. 29. ed. São Paulo: Saraiva, 2007.

Valle, Vanice Regina Lírio do. Políticas públicas, direitos fundamentais e controle judicial. Belo Horizonte: Fórum, 2009.

\section{Pesouisas do EditORIal}

\section{Veja também Doutrina}

- Layout processual penal na perspectiva constitucional, de Paulo Maycon Costa da Silva - RT 914/267;

- 0 debate sobre a descriminalização do aborto: aspectos penais e constitucionais, de Anelise Tessaro - RBCCrim 74/35; e

- Rever ou romper com a Constituição dirigente? Defesa de um constitucionalismo moralmente reflexivo, de José Joaquim Gomes Canotilho - RDCl 15/208. 